$\begin{array}{ll}\text { Abstracta Iranica } & \begin{array}{l}\text { Abstracta Iranica } \\ \text { Revue bibliographique pour le domaine irano-aryen }\end{array} \\ & \text { Volume } 22 \mid \mathbf{2 0 0 1} \\ & \text { Comptes rendus des publications de } 1999\end{array}$

\title{
al-Rasâ'il. Éd., introd et notes de Mohammad Beyraqdâr, Turquie, Qeysari, 1997.
}

Rédaction

\section{(2) OpenEdition}

Édition électronique

URL : http://journals.openedition.org/abstractairanica/36858

DOI : 10.4000/abstractairanica.36858

ISSN : 1961-960X

Éditeur :

CNRS (UMR 7528 Mondes iraniens et indiens), Éditions de l'IFRI

\section{Édition imprimée}

Date de publication : 15 mai 2001

ISSN : 0240-8910

\section{Référence électronique}

Rédaction, «al-Rasâill. Éd., introd et notes de Mohammad Beyraqdâr, Turquie, Qeysari, 1997. », Abstracta Iranica [En ligne], Volume 22 | 2001, document 391, mis en ligne le 17 février 2010, consulté le 13 octobre 2020. URL : http://journals.openedition.org/abstractairanica/36858 ; DOI : https:// doi.org/10.4000/abstractairanica.36858

Ce document a été généré automatiquement le 13 octobre 2020.

Tous droits réservés 


\section{al-Rasâ'il. Éd., introd et notes de Mohammad Beyraqdâr, Turquie, Qeysari, 1997.}

\section{Rédaction}

Édition des huit traités soufis de Qeyșarī, à savoir : 1) al-Muqaddamāt, 2) Kašf al-hijāab 'an kalām rabbì al-arbāb, 3) Risāla fì 'ilm al-tașawwuf, 4) Risāla fi ma'rifat al-mahabbat alhaqqīqiyya, 5) Asās al-wahdāniyya, 6) Nihāyat al-bayān fì dirāyat al-zamān, 7) Taḥqīq mā' alhayāat fi kašf asrār al-zalamāt, 8) Šarh ta'wīlāt al-basmallat al-naw'iyyat al-insāniyya.

\section{INDEX}

\section{Thèmes : 8 . Soufisme}

\section{AUTEURS}

\section{RÉDACTION}

Directeur de la revue et secrétariats (Paris et Téhéran) 